\title{
Antibacterial Activity of Lactic Acid Bacteria against Helicobacter pylori Evidence by in vivo and in vitro Studies
}

\author{
Nesreen Mohammed Nasr ${ }^{1 *}$, Manal Khider ${ }^{1}$, Wedad Metry $^{1}$ and Khaled Atallah ${ }^{2}$ \\ ${ }^{1}$ Department of Dairy Science, Faculty of Agriculture, Fayoum University, Fayoum, Egypt \\ ${ }^{2}$ Deptartment of Agricultural Microbiology, Faculty of Agriculture, Fayoum University,
} Fayoum, Egypt

*Corresponding author

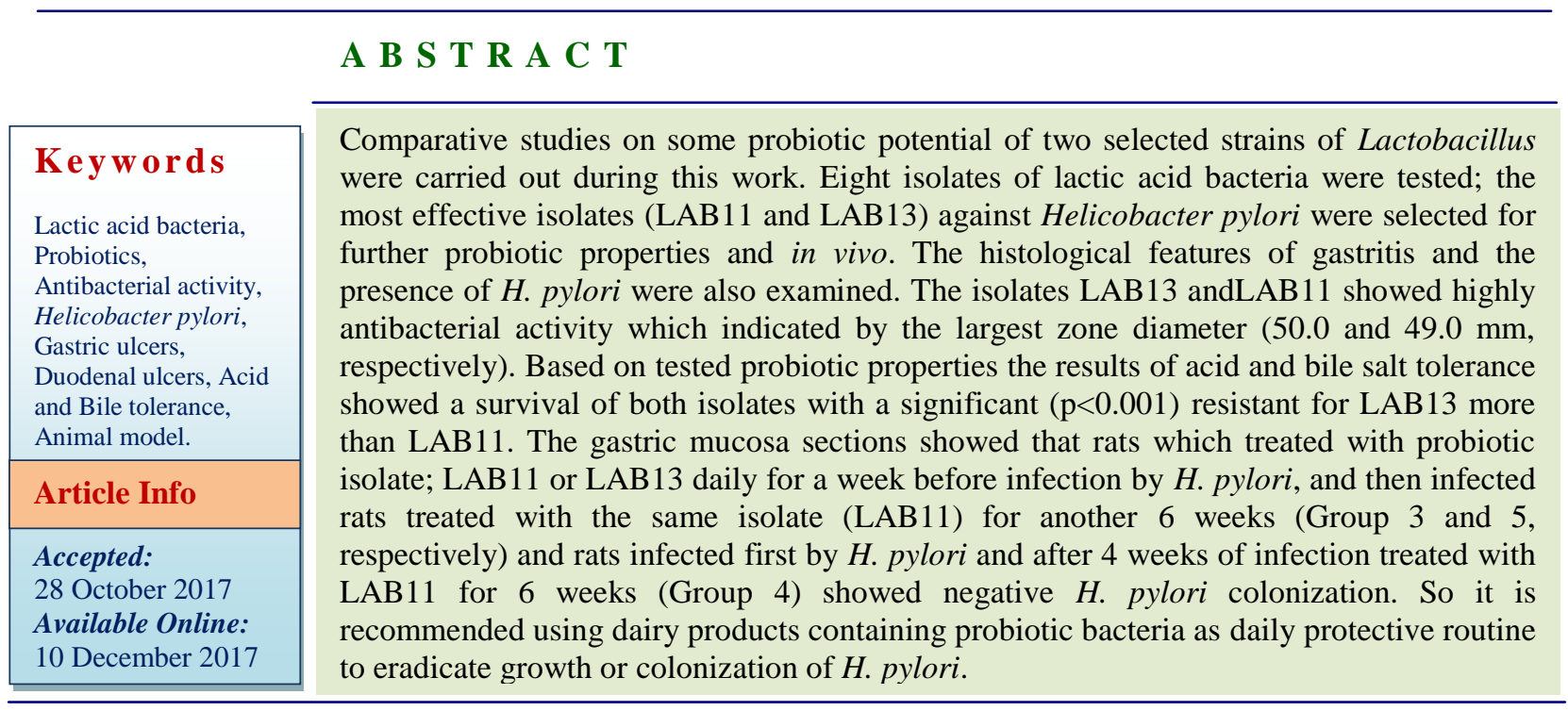

\section{Introduction}

Helicobacter pylori is an important gastroduodenal pathogen of humans (Larsen et al., 2013) and its infection is a growing public health problem with a prevalence rate of approximately 50\%, especially in the developing countries (Eshraghian, 2014; Nagy et al., 2016; Roberts, 2016). The infection by $H$. pylori when acquired in childhood and it will persist through life if a successful antimicrobial regimen is not performed (Mcnulty et al., 2012; Arslan et al., 2017). In spite of most infected individuals are asymptomatic; $H$. pylori infection is responsible for the development of chronic gastritis, functional dyspepsia, and gastric or duodenal ulcer (Smith et al., 2014). Although eradication therapies with antibiotics are presently available; but side effects and an increase for antibiotic resistance of $H$. pylori have been reported (Gerrits et al., 2006; Cheng et al., 2015).

Probiotics include several microorganisms, mostly within the genus of Lactobacillus; 
which can be defined as living microorganisms, which, upon ingestion in certain numbers, exert health benefits beyond inherent basic nutrition (FAO/WHO, 2001).

Lactic acid bacteria have the potential and ability to produce several important metabolites such as organic acids, probiotic properties and antimicrobial substances such bacteriocins, which attracted the attention of many researchers in recent years (Holzapfel $e t$ al., 2001; Khan et al., 2010). It is highly competitive largely due to their applications in the production of fermented food. Also they produce antimicrobial substances including bacteriocins that have ability to inhibit pathogenic and food spoilage bacteria. These compounds have shown to exert specific antagonistic properties against Gramnegative and Gram-positive pathogens.

Bacteriocins known as a kind of ribosomal synthesized and extra cellularly released antimicrobial peptides which become one of the weapons against microorganisms due to the specific characteristics of large diversity of structure and function, being stable to heat and it is natural resource (O'Sullivan et al., 2002; Cotter et al., 2005; Deegan et al., 2006; Rattanachaikunsopon and Phumkhachorn, 2010; Yang et al., 2014).

The beneficial effects of probiotics on gastrointestinal diseases have been widely described (Behnsen et al., 2013; Sarowska et al., 2013). Effects for the use of lactobacilli as additives in both human and animal diets were carried out (Hummel et al., 2007). In recent years, the probiotic activity of lactic acid bacteria has been emphasized. A number of health benefits have been claimed for probiotic bacteria and using it as a preventive approach to maintain the balance of intestinal microflora is also being recommended (Shah, 2007). It has beneficial effects on humans stabilization of intestinal microflora through preventing colonization of entero-pathogenic bacteria by adhesion to the intestinal wall and competition for nutrients (Denev, 2006) and also it stimulate the immune system (Isolauri et al., 2001).

Probiotic microorganisms should express high tolerance to acid and bile and ability to adhere to intestinal surfaces to survive in and colonise in gastro-intestinal tract. Thus, due to the gastric localization of $H$. pylori colonization and its relationships with gastric diseases; it is not surprising that several studies were carried out on the effects of probiotics on $H$. pylori. Numerous in vitro studies, demonstrating bacterial killing or inhibition, were followed by preclinical and clinical studies (Wilhelm et al., 2011; Patel et al., 2014). Moreover, probiotics have the potential to diminish side effects of antibiotics, increase the $H$. pylori eradication rate, and decrease host cell damage (LesbrosPantoflickova et al., 2007). So, aims of this work were to study the antibacterial activity of some Lactic acid bacteria isolates; LAB11 and LAB13 against $H$. pylori (in vitro) and select the most promising isolates to antagonize $H$. pylori in vivo study on rats.

\section{Materials and Methods}

\section{Activation of LAB isolates}

Ten isolates were used in this study; the isolates were obtained from the culture collection of Agricultural microbiology department, Faculty of Agriculture, Fayoum University, Egypt. From these isolates; LAB 11 and LAB13 were previously identified as Lactobacillus casei (Accession No. HQ177095) and Lactobacillus paracasei (Accession No.HQ177096.1), respectively (Elbanna et al., 2010; Khider and Elbanna, 2017; Elbanna et al., 2017). The isolates were activated in $10 \%(\mathrm{w} / \mathrm{v})$ sterilized skim milk at $37^{\circ} \mathrm{C}$ for $48 \mathrm{~h}$. 


\section{H. pylori and culture conditions}

H. pylori was obtained from Naval American Medical Research Unit 3, NAMRU-3) and activated in Columbia blood broth medium, then incubated for $48 \mathrm{~h}$ at $37^{\circ} \mathrm{C}$ under microaerophilic conditions in jars with the AnaeroGen Gas Packs (Oxoid, Basingstoke, UK).

\section{Preparation of cell-free culture supernatants (CFCSs)}

The cell-free culture supernatants of all LAB isolates were concentrated till $5 \%$ by using vacuum rotary evaporator at $40^{\circ} \mathrm{C}$ then used for further experiment. It kept at $4^{\circ} \mathrm{C}$ till determination of the antibacterial activity (Eied, 2008).

\section{Determination of the antibacterial activity of CFCSs}

The antibacterial activity of CFCSs was qualitatively tested by agar well diffusion method (Wolf and Gibbons, 1996). The clear zone diameters around each well were measured in $\mathrm{mm}$.

Some probiotic properties of selected lactic acid bacteria

\section{Determination of acid and bile salt} tolerance

The acid and bile salt tolerance of the strains was evaluated with the same method (Archer and Halami, 2015).To determine the acid tolerance; MRS broth was prepared at different $\mathrm{pH}$ values $(\mathrm{pH} \mathrm{2,3}$ and 4), then inoculated with $5 \%$ of fresh culture from both LAB11 and LAB13, in separate.

Aliquots from inoculated MRS broth for each isolate were taken at intervals of $0,1,2$ and $4 \mathrm{~h}$; serially diluted and plated onto MRS agar plates. After incubating anaerobically at $37{ }^{\circ} \mathrm{C}$ for $48 \mathrm{~h}$, the number of viable colonies was counted.

Bile tolerance was determined using MRS broth supplemented with different concentrations of bile salts $(0.3,0.5$ and $1 \%$ $w / v)$, which then inoculated with freshly prepared LAB strains, samples taken at zero time were used as a control. Bacterial growth was monitored as described in acid tolerance experiment.

In vivo $H$. pylori inhibition by lactic acid bacteria

\section{Experimental animal model and study design}

Sixty four Albino male rats same age of Sprague Dawley strain weighted $150 \pm 20$ gm were purchased from Food Technology Research Institute, Agricultural Research Center, Giza and housed in well aerated cages under hygienic condition. The rats were fed on basal diet for one week in the animal house of the previous research center for adaptation. In this study the rats were inoculated by gavage with $1 \mathrm{~mL} H$. pylori suspension $(5 \times$ $10^{8}-5 \times 10^{10} \mathrm{CFU} / \mathrm{mL}$ ) twice daily at an interval of $4 \mathrm{~h}$ for three consecutive days.

The lactic acid strains were used for preparinga fermented milk samples through inoculating heat treated skim milk withLAB11orLAB 13 at $37^{\circ} \mathrm{C}$ for $12 \mathrm{~h}$ until a viable count $10^{9}-10^{10} \mathrm{cfu} / \mathrm{mL}$ was achieved. The fermented milk was prepared every 7 days and stored at $4^{\circ} \mathrm{C}$ until use. A total of 64 rats were randomly assigned to the following eight groups $(n=8)$ as shown in Figure 1; Group 1: control negative (rats with noinfection) and Group 2: control positive (rats infected by $H$. pylori). Group 3: rats treated with probiotic isolate; LAB11 as a daily supplement in the animals' stomach for 
a week before infection by $H$. pylori, and then infected rats treated with the same isolate (LAB11) for another 6 weeks, Group 4: rats infected first by $H$. pylori and after 4 weeks of infection treated with LAB11 for 6 weeks and Group 5: rats infected first by $H$. pylori and after 6 weeks of infection treated with LAB11 for 6 weeks. The same for the next groups, Group 6: Rats treated with the other probiotic isolate; LAB13 as a daily supplement in the animals' stomach for a week before infection by $H$. pylori, after infection the rats treated with the same strain for another 6 weeks, Group 7: rats infected first by $H$. pylori and after 4 weeks of infection; treated with LAB13 for 6 weeks and Group 8: rats infected first by $H$. pylori and after 6 weeks of infection treated with LAB13 for 6 weeks.

At the end of each experiment, rats will be anesthetized and killed according to committee on animal research and ethics. The entire stomach and duodenum of the rats in each group will be dissected and examined for histological features of gastritis and the presence of $H$. pylori by Haemotoxylin and Eosin (H\&E) and Geimsa stain (Werawatganon, 2014).

\section{Statistical analysis}

Data were analyzed using General Linear Models (GLM) procedure of SPSS software (version 17.0.0). Duncan's multiple range tests was used to compare between the means (SPSS, 2008).

\section{Results and Discussion}

The antibacterial activity of CFCSs against H. pylori

All tested isolates against $H$. pylorishowed obvious clear inhibition zone with a significant differences $(\mathrm{p}<0.001)$ between them (Fig. 2). Among these isolates, Both
LAB13 and LAB11 showed the larger inhibition zone diameter (49.7 and $49.0 \mathrm{~mm}$, respectively) followed by LAB105 $(48.3 \mathrm{~mm})$ with no significant differences in between. It is noticed that there is no significant differences in diameter of the clear zone between the further tested isolates; LAB5, LAB25 and LAB100, where the diameters of the clear zone were 45.7, 45.7 and $46.0 \mathrm{~mm}$, respectively. Moreover, LAB107 showed the lowest inhibition zone diameter against $H$. pylori, which was $42.7 \mathrm{~mm}$.

Probiotics had an in vitro inhibitory effect on $H$. pylori so, it could present a low-cost alternative solution to prevent or decrease $H$. pylori colonization (Lesbros-Pantoflickova et al., 2007). Cats et al., (2003) found that culture and supernatants from $L$. casei grown in MRS medium significantly induced clear inhibition zone of $H$. pylori. Also, another study found that use of $L$. paracasei strain 06TCa19 may prevent $H$. pylori associated gastric inflammation (Takeda et al., 2017).

\section{Some probiotic properties of selected LAB isolates}

\section{Determination of acid and bile salt tolerance}

Based on the results obtained (Fig. 3); the survival of isolate LAB13 at zero time significantly $(p<0.001)$ achieving higher viability with $2.71 \times 10^{6} \mathrm{cfu} / \mathrm{ml}$ followed by the same isolate at 1 and $2 \mathrm{~h}$. (2.31 and $2.27 \times 10^{6} \mathrm{cfu} / \mathrm{ml}$, respectively). The samples show less viable probiotic cells at $\mathrm{pH} 2$ after exposure for 1-4 $\mathrm{h}$, which was less than the minimum requirement of viable probiotic cell $\left(10^{6} / \mathrm{ml}\right)$. From these results LAB13 isolate showed more resistant at low $\mathrm{pH}$ than isolate LAB 11 and the most suitable one for high growth was $\mathrm{pH}$ 4. The rate of bacterial survival as supplemented with bile salt was similar to the trend in acid tolerance test, with 
higher inhibition of growth seen as the bile concentrations increased for both LAB 11 and LAB13 isolates. Main effect of LAB isolates and different bile salt concentrations were shown in Figure 4. Media without bile salt acted as control for all experiments and it recorded the highest growth, significantly, $(p<0.001)$.

In general for both tested isolates, there is a gradual decline in viable count as the bile concentrations increased. Moreover, LAB13 was significantly more resistant to bile salts than LAB11 isolate with a viability of 4.08 and $3.17 \times 10^{6} \mathrm{cfu} / \mathrm{ml}$, respectively.

Probiotic bacteria must be acid and bile tolerant to survive in the human gastrointestinal tract and survive in the acidic $\mathrm{pH}$ of gastric juice to reach the small intestine and colonize, thereby imparting their benefits. The $\mathrm{pH}$ of gastric acid is 1.5 to $3.5 \mathrm{so}$; acid tolerance is accepted as one of the desirable properties used to select potentially probiotic strains (Marieb and Hoehn, 2010). Aciduric members such as L. acidophilus generally could not survive in low $\mathrm{pH}$ environment as these cells were proven to be vulnerable at $\mathrm{pH}$ 2.0 or below. It is thought that environments with low $\mathrm{pH}$ inhibit the metabolism activity and growth of lactobacilli, thus reducing the probiotics' viability (Sultana et al., 2000; Chan and Zhang, 2005; Sahadeva et al., 2011). Another study confirmed that the viability count of the bacteria declined tremendously when exposed to simulated gastric juice of $\mathrm{pH} 1.5$ after an incubation period of 3 hours (Mandal et al., 2006). The threshold point to determine acid resistance was set at $\mathrm{pH}$ value of 3.0 and incubation period of 3 as it simulates the residence time in the stomach (Haddadin et al., 2004). This is in accordance with findings from Liong and Shah (2005) which stated that resistance at $\mathrm{pH}$ 3 is set as standards for acid tolerance of probiotic culture. Therefore, result in Figure 3 indicates the strong inhibition on the viable bacteria numbers at $\mathrm{pH} 2$ was well supported.

Fig.1 In vivo $H$. pylori inhibition by LAB (Animal model)

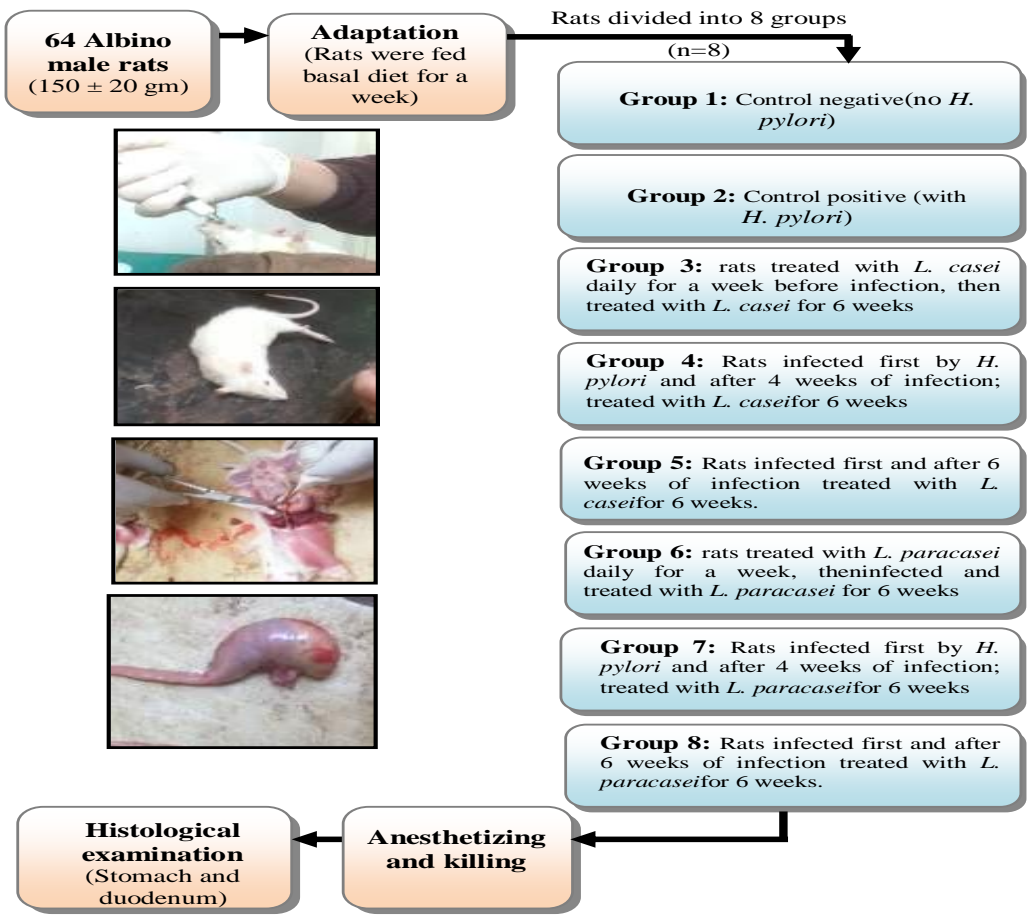


Fig.2 Effects of the cell-free culture supernatants (CFCSs) of 8 strains of LAB on inhibition zone diameter of $H$. pylori

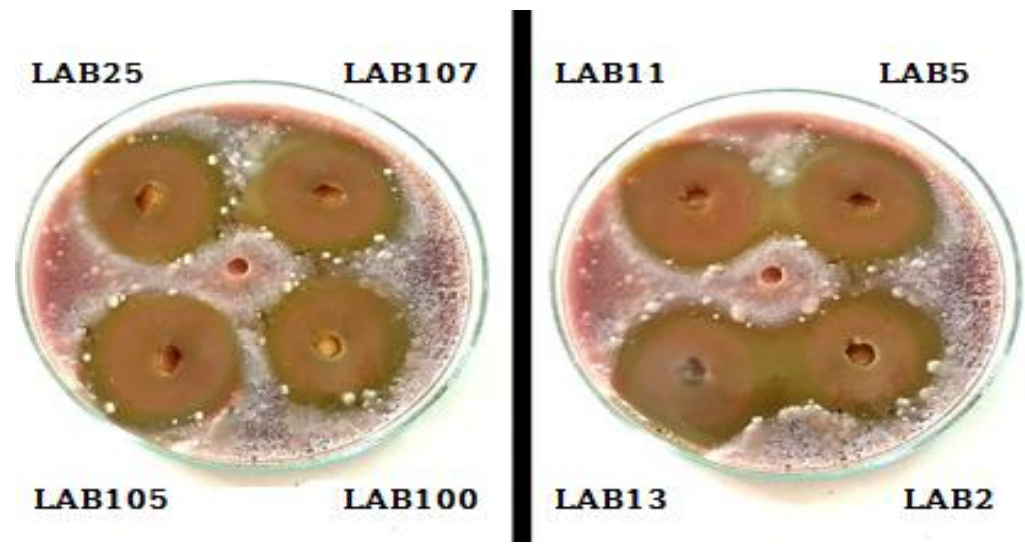

Fig.3 Variations of selected $\mathrm{LAB}$ isolates $(\mathrm{CFU} / \mathrm{mL})$ at different $\mathrm{pH}$ values

A: LAB 11

B: LAB 13

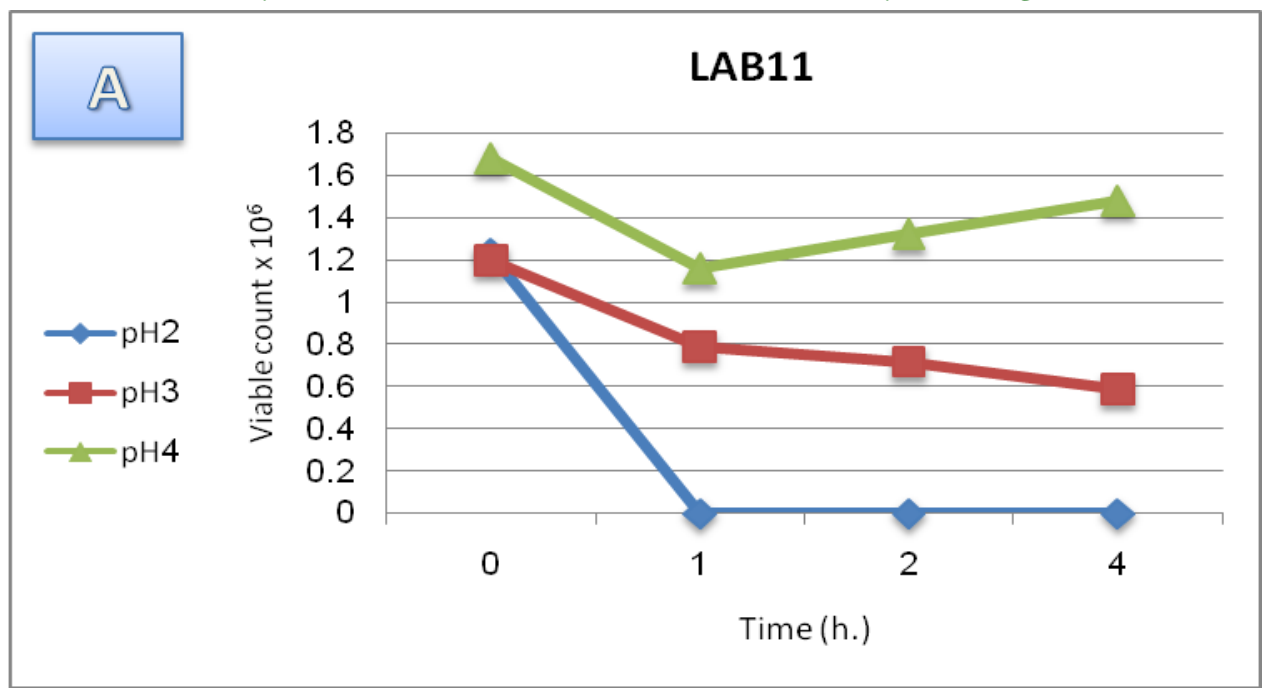

D)

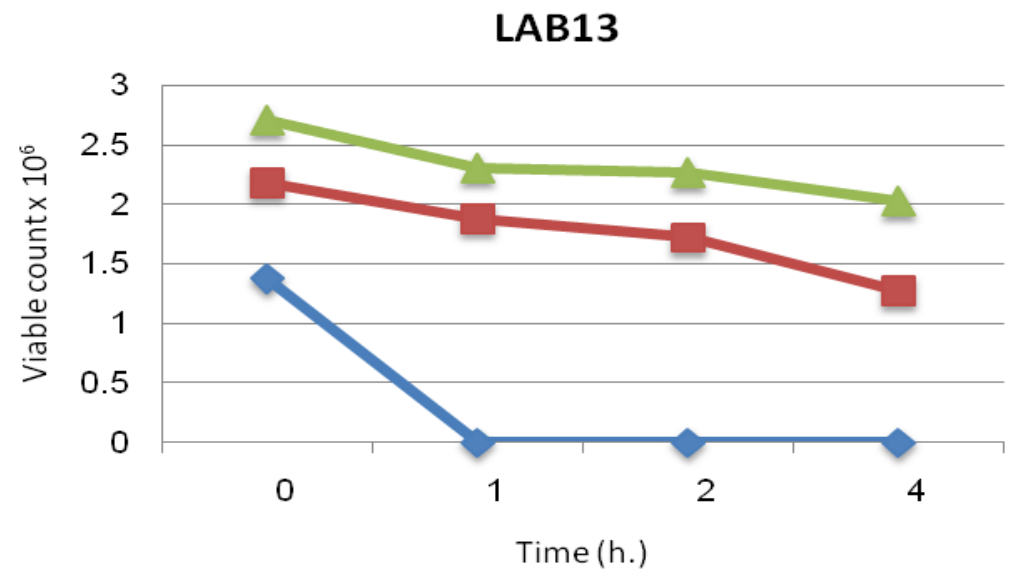


Fig.4 Variations of selected LAB isolates (CFU/mL) at different bile salts A: LAB 11 B: LAB 13
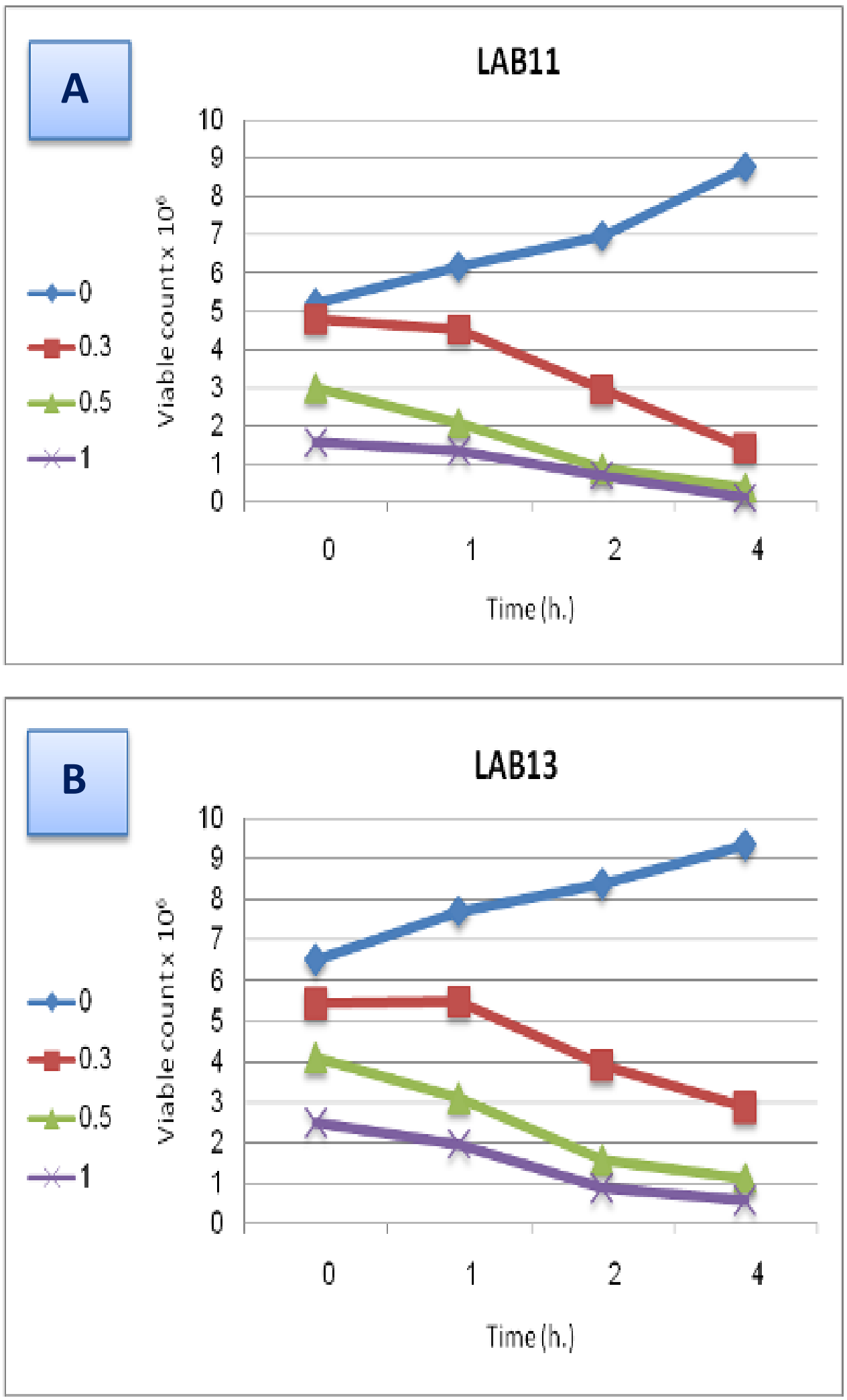
Fig.5 (x40): Histological examination in rats' gastric mucosa show the antibacterial effect of LAB isolates (LAB11 and LAB 13) on H. pylori. Group 1: Control negative. Sections show regular gastric glands with negative H. Pylori colonization. Group 2: Control positive. Sections show regular gastric glands with moderate H. Pylori colonization (arrows pointed). Group 3, 4 and 6: Sections show regular gastric glands with negative H. Pylori colonization. Group 7: Sections show regular gastric glands with low H. Pylori colonization (pointed with arrows).

Groups 5 and 8: Sections show regular gastric glands with low to moderate H. Pylori colonization (arrows pointed).
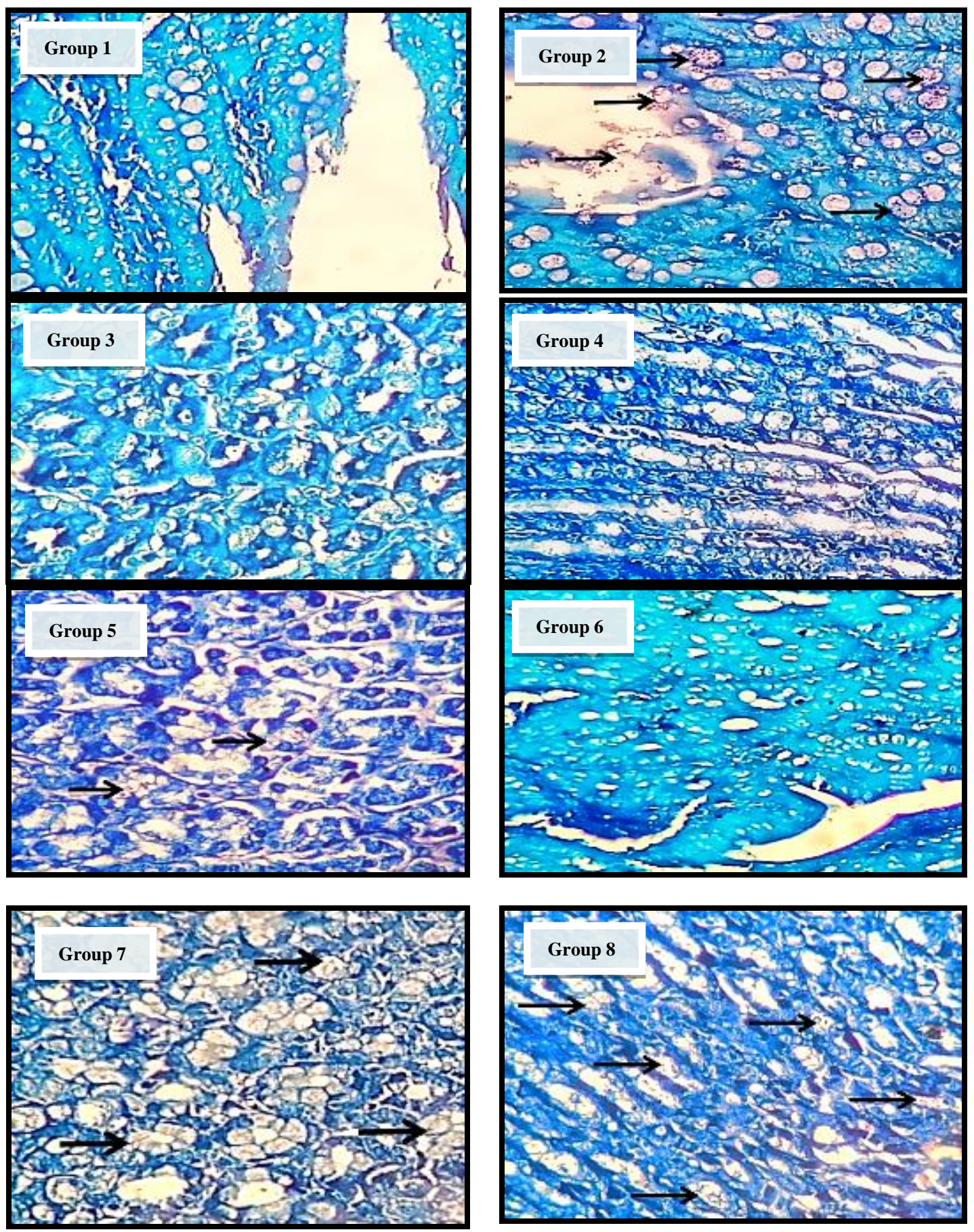
On the other hand, there was a study reported that bile salt did not inhibit the growth of the bacteria completely as even when subjected to a concentration of 2\% (Sahadeva et al., 2011). The protective effect of food matrix also may prevent the bacteria from bile exposure and hence, giving rises to the increased bile resistance of the strains (Begley et al., 2005). Suskovic et al., (2001) examined the survival and morphological changes of a potential probiotic strain, $L$. acidophilus M92, in the presence of bile salts and proved that bile salt hydrolyzes was active when tested on lactobacilli and showed a relatively strong resistance to bile salts. According to the previous obtained results of acid and bile salt tolerance for both tested lactic acid bacterial isolates (LAB11 and LAB 13) it is concluded that these isolates have probiotic properties.

\section{In vivo $H$. pylori inhibition by lactic acid bacteria as indicated by histological examination}

Data in Figure 5, illustrates the histological examination of gastritis and the presence of H. pylori by $\mathrm{H} \& \mathrm{E}$ and Giemsa staining of stomach and duodenum samples of the rats in each group. Results showed that the examination of group 1 recorded no $H$. pylori colonization as shown with Giemsa stained sections while in group 2 (positive control) with no probiotic treatment; $H$. pylori were present in a moderate to severe infestation. On the other hand, groups 3, 4 and 6 showed no $H$. pylori colonization in the gastric lumen. The severity of $H$. pylori colonization in groups 5 and 8 ranged from low to moderate. Moreover, in all members of group 7; $H$. pylori were described with low colonization.

Many studies dealing with either animal models or humans found that the most frequently used strains to assay their effect on $H$. pyroli infection were L. johnsonii La1 and L. rhamnosus $\mathrm{GG}$, either in a fermented milk preparation containing live bacteria or as a cell-free culture supernatant followed by other probiotics such as L. casei, L. acidophilus, Lactobacillus brevis, L. gasseri OLL2716, L. reuteri, $B$. lactis, $B$. animalis and $B$. breve (Felley et al., 2001; Gotteland and Cruchet, 2003; Myllyluoma et al., 2007). Various probiotics have shown favorable effects in animal models of $H$. pylori infection. In a mice model of infection, a probiotic combination containing L. acidophilus R0052 and L. rhamnosus R0011 was found to reduce the effects of $H$. pylori infection through reducing $H$. pylori colonization and alleviating $H$. pylori-induced inflammation of the stomach (Johnson-Henry et al., 2004). Another studies in a mice model demonstrated that L. casei strain Shirota and L. johnsonii La1, both administered in drinking water, attenuated $H$. pylori infectioninduced gastric mucosa inflammation. However, only L. casei strain Shirota was able to down regulate the colonization of $H$. pylori to gastric mucosa (Sgouras et al., 2004 and 2005). Also, L. gasseri was found to decrease colonization of clarithromycinresistant $H$. pylori (Ushiyama et al., 2003).

In the gastric mucosa, $H$. pylori possibly interact with epithelial cells through secretory components or as a result of adherence. There are several possible mechanisms by which probiotic bacteria can inhibit the adhesion of H. pylori (Lesbros-Pantoflickova et al., 2007). Certain lactobacilli such as L. johnsonii La1 (Michetti et al., 1999) or L. acidophilus LB (Coconnier et al., 1998) can exert their antiadhesion activity by secreting antimicrobial substances. In addition, strain such as $L$. reuteri (Mukai et al., 2002) can inhibit $H$. pylori growth by competing with adhesion sites. However, a nonspecific rather than a specific blockage of receptor sites is the most likely mechanism because lactobacilli can inhibit adhesion of large varieties of pathogenic bacteria, although each adheres to 
its particular receptor on the cells (Bernet et al., 1994). Animal studies demonstrated that previous colonization by probiotics prevented or reduced $H$. pylori infection in germfree mice (Johnson-Henry et al., 2004). Thus, regardless of the mechanisms involved in the inhibition of the adherence of $H$. pylori to epithelial cells, probiotics could prevent $H$. pylori colonization of the gastric mucosa by inhibiting its adhesion to epithelial cells.

The ability of some probiotic strains to increase mucin production can protect the gastric mucosal barrier against the adherence of pathogenic bacteria such as $H$. pylori and also inhibiting its adhesion to epithelial cells. According to the obtained results; it can be concluded that both strains of LAB 11 andLAB 13, exhibit antibacterial activity against $H$. pylori. Also, both strains are probiotics as they were resistant to acidic $\mathrm{pH}$ and bile salts concentrations. Moreover, both isolates were tested for in vivo (rat model) and the histological examination of gastric mucosa showed that groups which treated with each isolate daily for a week before the initial $H$. pylori infection and the group that treated with LAB 11 after 4 weeks of infection had regular gastric glands with negative $H$. Pylori colonization like negative control group. Sections of all other groups showed regular gastric glands with $H$. Pylori colonization less than positive control. So, we recommend using dairy products containing probiotic bacteria such lactic acid bacteria ( $L$. casei, L. paracasei) as a daily protective routine to prevent infection with $H$. pylori.

\section{References}

Archer, A. C., and Halami, P. M. 2015. Probiotic attributes of Lactobacillus fermentum isolated from human feces and dairy products Appl. Microbiol. Biotechnol., 99: 8113-8123.

Arslan, N., Yılmaz, O., Demiray-Gürbüz, E.
2017. Importance of antimicrobial susceptibility testing for the management of eradication In Helicobacter pylori infection. World $\mathrm{J}$ Gastroenterol; 23(16): 2854-2869

Begley, M., Gahan, C., Hill, C. 2005. The interaction between bacteria and bile. FEMS Microbiology Reviews; 29: 625651.

Behnsen, J., Deriu, E., Sassone-Corsi, M., Raffatellu, M. 2013. Probiotics: properties, examples, and specific applications. Cold Spring HarbPerspect Med; 3: A010074

Bernet, M.F., Brassart, D., Neeser, J.R., Servin, A.L. 1994. Lactobacillus acidophilus LA1 binds to cultured human intestinal cell lines and inhibits cellattachment and cell invasion by enterovirulent bacteria. Gut.; 35:483-9

Cats, A., Kuipers, E.J., Bosschaert, M.A., Pot, R.G., Vandenbrouckegrauls, C.M, Kusters, J.G. 2003. Effect of frequent consumption of a Lactobacillus caseicontaining milk drink in Helicobacter pylori-Colonized Subjects. Aliment PharmacolTher; 17: 429-435.

Chan, E.S., Zhang, Z. 2005. Bioencapsulation by compression coating of probiotic bacteria for their protection in an acidic medium. Process Biochemistry; 40:3346-3351.

Cheng, A., Sheng, W.H., Liou, J.M. 2015. Comparative In Vitro antimicrobial susceptibility and synergistic activity of antimicrobial combinations against Helicobacter pylori Isolates In Taiwan. J MicrobiolImmunol Infect.; 48:72-9.

Coconnier, M.H., Lievin, V., Hemery, E., Servin, A.L. 1998. Antagonistic activity against Helicobacter infection in vitro and in vivo by the human Lactobacillus acidophilus strain LB. Appl Environ Microbiol.; 64: 4573-80.

Cotter, P.D., Hill, C., Ross, R.P. 2005 Bacteriocins: developing innate 
immunity for food. Nat. Rev. Microbiol; 3, 777-788.

Deegan, L.H., Cotter, P.D., Hill, C., Ross, P. 2006. Bacteriocins: Biological tools for bio-preservation and shelf-life extension. International Dairy Journal; 16: $1058-1071$.

Denev, S.A. 2006. Role of Lactobacilli in gastrointestinal ecosystem. Bulgarian Journal of Agricultural Science; 12(1): 63-114.

Eied, Y.F. 2008. Characterization Of Bacteriocin - Like substances produced by some local Lactobacillus isolates. M. Sc. Thesis, Fac. Agric., Fayoum Univ., Egypt.

Elbanna, K., Hassan, G., Khider, M., Mandour, R. 2010. Safe biodegradation of textile azo dyes by newly isolated lactic acid bacteria and detection of plasmids associated with degradation. $\mathbf{J}$ Bioremed. Biodegrad; 1:112.

Elbanna, K., Sarhan, O.M., Khider, M., Elmogy, M., Abulreesh, H.H. and Shaaban, M.R. 2017. Microbiological, histological and biochemical evidence for the adverse effects of food azo dyes on rats; 25: 667-680.

Eshraghian, A. 2014. Epidemiology Of Helicobacter pylori Infection Among The healthy population in iran and countries of the Eastern Mediterranean region: a systematic review of prevalence and risk factors. World J Gastroenterol; 20(46): 17618-17625

FAO/WHO Expert Consultation, 2001. Health And Nutritional Properties Of Probiotics In Food Including Powder Milk With Live Lactic Acid Bacteria. Córdoba, Argentina 1-4 Oct. Available From:Http://Www.Who.Int/Foodsafety/ Publications/Fs_Management/En/Probio tics.Pdf

Felley, C.P., Corthe'Sy-Theulaz, I., Rivero, J.L., Sipponen, P, Kaufmann, M, Bauerfeind, P. 2001. Favourable Effect
Of An Acidified Milk (LC-1) On Helicobacter pylori Gastritis In Man. Eur J Gastroenterol Hepatol;13:25.

Gerrits, M.M., Van Vliet, A.H., Kuipers, E.J. 2006. Helicobacter pylori and antimicrobial resistance: molecular mechanisms and clinical implications. Lancet Infect Dis.; 6:699-709.

Gotteland, M. and Cruchet, S. 2003. Suppressive effect of frequent ingestion of Lactobacillus johnsonii La1 on Helicobacter pylori colonization in asymptomatic volunteers. J Antimicrob Chemother;51:13-17

Haddadin, M.S.Y., Awaisheh, S.S., Robinson, R.K. 2004. The production of yoghurt with probiotic bacteria isolated from infants in Jordan. Pakistan Journal of Nutrition; 3 (5): 290-293

Holzapfel, W.H., Haberer, P., Geisen, R., Bjorkroth, J., Schillinger, U. 2001. Taxonomy and important features of probiotic microorganisms in food nutrition. Am. J. Clin. Nutr.; 73, 365S373S.

Hummel, A.S., Hertel, C., Holzapfel, W.H., Franz, C. 2007. Antibiotic resistance of starter and probiotic strains of Lactic acid bacteria. Applied and Environmental Microbiology; 73(3): 730-739.

Isolauri, E., Sutas, Y., Kankaanpaa, P., Arvilommi, H., Salminen, S. 2001. Probiotics: effects of immunity. American Journal of Clinical Nutrition; 73 (2 Suppl): S444-S450.

Johnson-Henry, K.C., Mitchell, D.J., Avitzur, Y., Galindo-Mata, E., Jones, N.L., Sherman, P.M. 2004. Probiotics Reduce Bacterial Colonization And Gastric Inflammation In $H$. Pylori-Infected Mice. Dig Dis Sci.;49: 1095-1102.

Khan, H., Flint, S., Yu, P.L. 2010. Enterocins in food preservation. Int $\mathbf{J}$ Food Microbiol.; 141: 1-10.

Khider, M., Elbanna, K. 2017.Extending the 
shelf life of camembert cheese via controlling over-ripening by bacteriocin of newly lactic acid bacterial isolate LAB100. International J Nutr Food Sci; 6(2):88-98

Larsen, A.L., Ragnhildstveit, E., Moayeri, B., Eliassen, L., Melby, K.K. 2013. Resistance rates of metronidazole and other antibacterials in Helicobacter pylori from previously untreated patients in Norway. APMIS; 121: 353358.

Lesbros-Pantoflickova, D., Corthe'SyTheulaz, I., Blum, A.L. 2007. Helicobacter pylori and probiotics. J Nutr; 137: 812S-8S.

Liong, M.T., Shah, N.P. 2005. Acid and bile tolerance and cholesterol removal ability of lactobacilli strains. Journal of Dairy Science; 88: 55-66.

Mandal, S., Puniya, A.K., Singh, K. 2006. Effect of alginate concentration on survival of encapsulated Lactobacillus casei NCDC-298. International Dairy Journal; 16: 1190-1195.

Marieb, E.N. and Hoehn, K. 2010. Human anatomy \& physiology. San Francisco: Benjamin Cummings.

Mcnulty, C.A., Lasseter, G., Shaw, I., Nichols, T., D'Arcy, S., Lawson, A.J., Glocker, E. 2012. Is Helicobacter pylori antibiotic resistance surveillance needed and how can it be delivered? Aliment PharmacolTher.; 35: 1221-1230.

Michetti, P., Dorta, G., Wiesel, P.H., Brassart, D., Verdu, E., Herranz, M., Felley, C., Porta, N., Rouvet, M. 1999. Effect of whey-based culture supernatant of Lactobacillus acidophilus (johnsonii) La1 on Helicobacter pylori infection in humans. Digestion., 60: 203-209.

Mukai, T., Asasaka, T., Sato, E., Mori, K., Matsumoto, M., Ohori, H. 2002. Inhibition of binding of Helicobacter pylori to the glycolipid receptors by probiotic Lactobacillus reuteri. FEMS
Immunol Med Microbiol.; 32:105-110. Myllyluoma, E., Veijola, L., Ahlroos, T., Tynkkynen, S., Kankuri, E., Vapaatalo, H. 2007. Probiotic supplementation improves tolerance to Helicobacter pylori eradication therapyda placebocontrolled, double-blind, randomized pilot study. Aliment PharmacolTher.; 21:1263-1272.

Nagy, P., Johansson, S., Molloy-Bland, M. 2016. Systematic review of time trends in the prevalence of Helicobacter pylori infection in China and the USA Gut Pathog; 8: 8 .

O'Sullivan, L., Ross, R.P., Hill, C. 2002. Review: Potential of bacteriocinproducing lactic acid bacteria for improvements in food safety and quality. Biochimie, 84, 593-604.

Patel, A., Shah, N., Prajapati, J.B. 2014. Clinical application of probiotics in the treatment of Helicobacter pylori infection-a brief review. J MicrobiolImmunol Infect; 47: 429-437

Rattanachaikunsopon, P. and Phumkhachorn, P. 2010. Lactic acid bacteria: their antimicrobial compounds and their uses in food production. Annals of Biological Research.; 1(4): 218-228.

Roberts, S.E., Morrison-Rees, S., Samuel, D.G., Thorne, K., Akbari, A., Williams, J.G. 2016. Review article: the prevalence of Helicobacter pylori and the incidence of gastric cancer across Europe. Aliment PharmacolTher; 43 (3), 334-345

Sahadeva, R.P.K., Leong, S.F., Chua, K.H., Tan, C.H., Chan, H.Y., Tong, E.V., Wong, S.Y.W., Chan, H.K. 2011. Survival of commercial probiotic strains to $\mathrm{pH}$ and bile. International Food Research Journal; 18(4): 1515-1522

Sarowska, J., Choroszy-Król, I., RegulskaIlow, B., Frej-Mądrzak, M., JamaKmiecik, A. 2013. The therapeutic effect of probiotic bacteria on 
gastrointestinal diseases. AdvClinExp Med; 22: 759-766

Sgouras, D., Maragkoudakis, P., Petraki, K., Martinez-Gonzalez, B., Eriotou, E., Michopoulos, S. 2004. In vitro and in vivo inhibition of Helicobacter pylori by Lactobacillus casei strain Shirota. Appl Environ Microbiol; 70: 518-526.

Sgouras, D.N., Panayotopoulou, E.G., Martinez-Gonzalez, B., Petraki, K., Michopoulos, S., Mentis, A. 2005. Lactobacillus johnsonii La1 attenuates helicobacter pylori-associated gastritis and reduces levels of pro-inflammatory chemokines in C57BL/6 mice. ClinDiagn Lab Immunol.; 12: 13781386.

Shah, N.P. 2007. Functional cultures and health benefits. International Dairy Journal; 17(11): 1262-1277.

Smith, S.M., O’Morain, C., Mcnamara, D. 2014. Antimicrobial susceptibility testing for Helicobacter pylori in times of increasing antibiotic resistance. World J Gastroenterol; 20: 9912-9921.

Spss. Statistical Package For Social Sciences. Version 17.0.0, Spss Corporation, 2008.

Sultana, K., Godward, G., Reynolds, N., Arumugaswamy, R., Peiris, P., Kailasapathy, K. 2000. Encapsulation of probiotic bacteria with alginate-starch and evaluation of survival in simulated gastrointestinal conditions and in yoghurt. International Journal of Food Microbiology; 62: 47-55.

Suskovic, J., Kos, B., Matosic, S., Besendorf, V. 2001. The effect of bile salts on survival and morphology of a potential probiotic strain. World Journal of Microbiology \& Biotechnology; 16: 673-678.

Takeda, S., Igoshi, K., Tsend-Ayush, C., Oyunsuren, T., Sakata, R., Koga, Y., Arima, Y., Takeshita, M. 2017. Lactobacillus paracasei strain 06tca19 suppresses inflammatory chemokine induced by Helicobacter pylori in human gastric epithelial cells. Hum Cell. 2017 Oct; 30(4): 258-266

Ushiyama, A., Tanaka, K., Aiba, Y., Shiba, T., Takagi, A., Mine, T. 2003. Lactobacillus gasseri OLL2716 as a probiotic in clarithromycin resistant Helicobacter pylori infection. J Gastroenterol Hepatol; 18: 986-991.

Werawatganon, D. 2014. Simple animal model of Helicobacter pylori infection. World Journal of Gastroenterology; 20(21): 6420-6424.

Wilhelm, S.M., Johnson, J.L., Kale-Pradhan, P.B. 2011. Treating bugs with bugs: the role of probiotics as adjunctive therapy for Helicobacter pylori. Ann Pharmacother; 45: 960-966

Wolf, C.E. and Gibbons, W.R. 1996. Improved method for quantification of the bacteriocin nisin. J. Appl.Bacteriol.; 80: 453 .

Yang, S.C., Lin, C.H., Sung, C.T., Fang, J.Y. 2014. Antibacterial activities of bacteriocins: application in foods and pharmaceuticals. Frontiers in Microbiology; 5: 1-10.

\section{How to cite this article:}

Nesreen Mohammed Nasr, Manal Khider, Wedad Metry and Khaled Atallah. 2017. Antibacterial Activity of Lactic Acid Bacteria against Helicobacter pylori Evidence by in vivo and in vitro Studies. Int.J.Curr.Microbiol.App.Sci. 6(12): 4235-4247.

doi: https://doi.org/10.20546/ijcmas.2017.612.488 